\title{
DIDACTICAS
}




\section{CLAVES PARA LA ENSEÑANZA DE LA HISTORIA}

\section{Jaime Jaramillo Uribe $y_{*}$ Jorge Orlando Melo*}

\section{Nota introductoria}

El presente trabajo es resultado de un informe que los autores rindieron al Ministerio de Educación Nacional durante los años setenta. El objetivo era ofrecer orientaciones teóricas y prácticas a los profesores de la enseñanza primaria y secundaria encargados de los cursos de historia de Colombia. Siguiendo las orientaciones de la moderna historiografía, los autores subrayan la importancia de los conceptos y el valor estratégico de los ejemplos para conferir vida a los marcos de referencia. Por la claridad, la pericia de los autores y el acervo bibliográfico que acompaña el ensayo, los editores de la Revista Colombiana de Educación creen que su difusión sería de gran utilidad para los maestros en ejercicio y para los programas de didáctica de la historia que actualmente se ofrecen en las Facultades de Educación.

Ambos autores tienen una amplia experiencia no sólo en el ámbito de la docencia sino en el campo del diseño y promoción de textos para la enseñanza. Jaime Jaramillo Uribe, egresado de la Escuela Normal Superior y en una época director de su escuela anexa -la institución adjunta destinada a las prácticas pedagógicas-, fue el director científico del Manual de historia de Colombia (1978-80), la obra colectiva que tantos servicios ha prestado a la propagación de los estudios históricos en nuestro medio. Algo similar ocurre con Jorge Orlando Melo, quien ha destinado buena parte de su esfuerzo académico a promover vastos programas de divulgación. Durante los últimos quince años su nombre ha estado vinculado con los proyectos nacionales más ambiciosos de difusión de materiales históricos. Es el editor de la Historia de Antioquia (1988), uno de los asesores de la Nueva Historia de Colombia (1989), el director académico de varias entregas de la Grau Enciclopedia de Colombia (1991), el editor de la Historia de Medellín (1996) y el actual animador científico de Credencial Historia, el intento de mayor envergadura realizado en el país por llevar la reflexión histórica a manos del gran público. A esto se suma su texto Raíces 5 (1989), un manual escolar que ha vendido más de 60.000 ejemplares en el competido mundo de las cartillas destinadas a la enseñanza primaria.

El texto de Jaramillo Uribe y Melo ofrece una cuidadosa bibliografía para nutrir los temas objeto de estudio. Como buena parte de ella se ha enriquecido en los últimos años con investigaciones nacionales y extranjeras, los editores de la Revista Colombiana de Educacion sugieren a los lectores remitirse a la actualización bibliográfica hecha por J. O. Melo en su libro Historiografía colombiana, realidades y perspectivas (Medellín, 1996). Allí podrán encontrar un completo inventario de obras generales y libros especializados sobre el mundo precolombino, el Descubrimiento, la Conquista, la Colonia, la Independencia y los siglos XIX y XX. Esta bibliografía

\footnotetext{
" Jaime Jaramillo Uribe, historiador, profesor de la Universidad de Los Andes y autor de numerosos trabajos sobre la Colonia y el siglo XIX. Jorge Orlando Melo, historiador, autor de libros sobre la historiografía colombiana, el descubrimiento. la conquista y el siglo XIX. En la actualidad se desempeña como director de la Biblioteca Luis Ángel Arango del Banco dc la República.
} 
viene acompañada de breves y provocativos comentarios dirigidos a facilitar su consulta ya promover su estudio por parte de estudiantes y profesores.

G. Cataño

\section{Objetivos}

1. El programa está dividido para que los alumnos obtengan un conocimiento integral de la Historia de Colombia, que comprenda sus instituciones sociales, políticas y culturales, a través de sus datos más significativos. El conocimiento histórico debe lograr que el estudiante aprenda a pensar los hechos de la Historia en sus conexiones hacia adentro y hacia fuera, es decir, a relacionar en sus influencias mutuas los hechos inmediatos que pertenecen a la propia realidad colombiana y a éstos con los hechos exteriores que pertenecen a la Historia Universal directamente ligada a la nacional. Por ejemplo, durante el período colonial la vida de las colonias no puede aislarse de los aconteceres de la metrópoli española. Las guerras que sostenía España en los siglos XVI, XVII y XVIII, repercutían en las colonias en forma de medidas políticas, económicas y culturales. Lo mismo ocurría con los cambios en la orientación de la cultura o la educación de la metrópoli. No podrían entenderse, por ejemplo, el movimiento de la Expedición Botánica y las tendencias de las ideas en la Nueva Granada a fines del siglo XVIII, sin relacionarlas con la política cultural de los Borbones españoles en la misma época. Podríamos tomar también el caso de la independencia. No sería posible comprenderla sin hacer referencia a hechos como la invasión de Napoleón.

Algo semejante podría decirse si pasamos al siglo XIX. Uno de los resultados del movimiento de independencia fue abrir el país al contacto con el mundo, especialmente con países europeos y con los Estados Unidos. El estudiante debe aprender a ver las relaciones que se fueron presentando con la historia de esos países, los nuevos flujos educativos, tecnológicos, económicos, políticos que recibió el país y la influencia que los hechos de la política mundial pudieron tener en la Nueva Granada. Un objetivo básico del programa y de su enfoque metodológico, es acostumbrar al estudiante a ver la Historia Colombiana Como una parte, un aspecto de la Historia Universal, por lo menos del sector de la Historia Universal más directamente ligado a la Historia Nacional como es la de Europa (España, Inglaterra, Francia), la de los países hispanoamericanos y la de los Estados Unidos. No puede llegarse a una verdadera comprensión de la Historia Nacional si no se establecen estas relaciones. Así se aprende simultáneamente la Historia Nacional y la Universal, en una conexión que las hace más interesantes e inteligibles.

2. Un segundo objetivo sería llevar al estudiante la idea de que la Historia tiene hechos significativos para la vida de los pueblos y que ella no está hecha de anécdotas y nimiedades. Por lo tanto que el aprendizaje de la Historia no es una cuestión de memorizar datos. fechas y anécdotas de sus hombres, sino una labor de razonamiento metódico, sobre los hechos y circunstancias. En fin, que como hemos dicho, los hechos de la historia no aparecen al azar o al capricho de los hombres sino que siguen una lógica y entre ellos existen unas relaciones de condicionamiento. Que la voluntad del hombre puede modificar las circunstancias en que se desarrolla su vida, pero hasta cierto límite y en todo caso tomando en cuenta las circunstancias que le ponen límites a esa voluntad.

3. El programa y la metodología respectiva tienen también por objeto lograr que el conocimiento histórico no sea un cúmulo de datos eruditos, que atiborran la mente de datos, fechas y nombres sino un medio para dar al individuo una capacidad de 
razonamiento para comprender los fenómenos políticos, sociales y culturales que forman la materia de la historia.

4. La enseñanza de la Historia, tal como se plantea en el programa, busca también formar una conciencia nacional firme y positiva. No se trata de fomentar el chauvinismo, ni una deformada actitud nacionalista, pero sí un sentimiento de orgullo y una valoración positiva de la tradición nacional, de sus valores humanos y de lo que los colombianos han hecho en medio de grandes dificultades, en un medio hostil, a base de su propio esfuerzo y muchas veces en lucha con poderes e intereses externos.

5. El anterior objetivo no es antagónico con la idea de que la Historia puede ayudar a formar una conciencia de solidaridad humana y de la necesidad de interdependencia entre los pueblos y culturas. Las referencias comparativas permitirán ver lo que todos los pueblos han aportado al bienestar y al progreso del hombre.

6. La Historia deberá desarrollar también valores morales como la tolerancia, el amor a la verdad y valores vitales y científicos como el sentido de la realidad y el rigor en las opiniones y juicios sobre hombres, pueblos y circunstancias. El profesor de historia no deberá hacer afirmaciones sin la debida documentación, ni la adecuada prueba. Así desarrolla el sentido de responsabilidad en el juicio. Al mostrar condiciones reales en que tienen que desarrollarse las empresas históricas y las grandes dificultades que los pueblos tienen para lograr ciertos objetivos, desarrolla el sentido de la realidad y el verdadero criterio histórico que es lo contrario de la utopía y de las ilusiones del hombre sin educación. Piénsese, por ejemplo, en las condiciones de ruina económica en que quedó Colombia después de la guerra de la independencia o de sus guerras civiles y las dificultades que tenían los colombianos para rehacer la organización política, reconstruir la economía, etc., o en los obstáculos que la naturaleza tropical, su condición de país dependiente de la economía de las grandes potencias le presentan al desarrollo de su industria o a la formación de la riqueza.

7. Finalmente, el programa y la metodología respectiva tienen por objeto enseñar al estudiante a orientarse en el mundo de los problemas sociales y políticos. La Historia se ve en el programa como una síntesis de la realidad social, compuesta de hechos económicos, políticos, culturales. El cuidado de un país moderno, de una democracia participante, debe tener una buena información sobre estos hechos y estar en capacidad de relacionarlos y comprenderlos.

\section{Sugerencias metodológicas y didácticas}

1. El profesor debe partir de la base de que la Historia no es un proceso arbitrario e irracional, pero que tampoco sigue unas leyes absolutas, tan lógicas como las que siguen algunos procesos de la naturaleza. No hay una ni varias leyes que nos expliquen la Historia, ni nos permitan prever el futuro. Pero sí hay unas tendencias generales que pueden observarse en la historia del hombre y en la historia particular de una nación como Colombia. Existen hechos y fenómenos de la geografía, la economía y la acción social con los cuales los hombres que hacen la historia tienen que contar. Algunos de estos hechos son modificables por su voluntad; ante otros no tiene más remedio que adaptarse a ellos. Cada época histórica y cada país tienen factores específicos que ponen unos limites a la acción del hombre. El profesor y el historiador deben saber descubrirlos, señalarlos y explicarlos. 
2. La Historia es una sucesión de cambios en todos los órdenes de la vida de una nación o de una cultura. Sin embargo, no todos los aspectos de la vida social cambian al mismo ritmo, ni el ritmo de cambio es el mismo en todas las épocas y en todas las culturas. Así, el ritmo de cambio de la cultura europea es más rápido que el de la cultura hindú, por ejemplo, y el de la época moderna de Latinoamérica más rápido que el de su época colonial. La tecnología cambia más rápidamente que el lenguaje y que las actitudes mentales. Hay aspectos de la cultura afectados de más estática que otros. Las culturas rurales son más conservadoras que las urbanas.

3. La comparación es un fecundo método en la Historia y en las Ciencias Sociales. Con razón se ha dicho que representa en ellas lo que el experimento es en las Ciencias Naturales. Si comparamos dos culturas o la historia de dos naciones, seguramente no encontramos dos procesos, ni dos formas de cultura exactamente iguales. Pero las analogías y los mismos contrastes ayudarán a comprender uno y otro caso.

4. El profesor de Historia debe evitar las antítesis absolutas en la explicación histórica. ¿Quiénes desempeñan papel más importante, las personalidades, los grandes héroes o las masas o las clases sociales? ¿Cuáles son los factores decisivos, los económicos, los políticos, los culturales? El buen criterio histórico es el que analizan estos factores según épocas, naciones, circunstancias. Por ejemplo, es muy posible que los factores religiosos nos expliquen más hechos y manifestaciones de la Edad Media y que los factores económicos sean más importantes en la historia de la sociedad industrial moderna.

5. El profesor de Historia y de Ciencias Sociales debe manejar un conjunto de conceptos, tales como: esclavismo, feudalismo, capitalismo. socialismo, burguesía, proletariado, democracia, etc. El buen conocedor de la Historia sabe que no debe tomarse estos conceptos tipos, como abstracciones que ayudan a caracterizar una época o una sociedad, pero que adquieren también matices y formas particulares en pueblos y naciones, en épocas y períodos. Además, que varias de estas formas de presentarse la vida cultural, la vida social o política pueden coincidir en una época o en pueblo. Por ejemplo, en un país como Colombia pueden coincidir formas de organización capitalista (industria moderna de las ciudades) y formas semifeudales en la vida agrícola (campesinos endeudados a través del arrendamiento de tierras, que pierden por eso su movilidad y están prácticamente ligados a la propiedad del dueño de la tierra). La democracia moderna adquiere muchas formas y manifestaciones. Puede estar muy desarrollada en Inglaterra, pero es imperfecta y apenas constituye un ideal en muchos países del mundo, sobre todo del llamado hoy tercer mundo o mundo del subdesarrollo. Hay una burguesía europea, vieja, con una cultura y una forma de vida muy precisa (como por ejemplo en Francia), pero la burguesía en otros países (es el caso de Latinoamérica) está apenas en desarrollo, es relativamente joven y tiene muchos rasgos culturales y sicológicos propios de estos países, de su tradición y su cultura específica.

6. Finalmente, algunas observaciones sobre las condiciones personales (subjetivas y objetivas) que debe tener un profesor de Historia o de Ciencias Culturales y sociales.

a) Conocimientos básicos de economía, geografía y ciencia política. Hoy no puede comprenderse la Historia sin saber cómo produce un pueblo su riqueza y las bases de su vida material. Sin conocer sus técnicas de trabajo y producción y sin saber cómo está organizada la propiedad y goce de los bienes económicos. Tampoco sin saber en qué tipo de hábitat se desarrolló y qué obstáculos o condiciones positivas le presenta dicho hábitat. Tampoco pueden ignorarse sus instituciones políticas y las transformaciones que sufre el Estado, así como las relaciones entre éste y sus miembros o ciudadanos. 
b) Un buen profesor de Historia debe poder manejar conceptos y cifras estadísticas. No para atiborrar de ellas al estudiante, pero sí para ilustrar claramente algunos fenómenos demográficos y económicos.

e) Otra antítesis rígida que debe evitarse es la que enfrenta historia cronológica, a base de fechas e historia de grandes hechos y grandes formas de la cultura o la vida social. No debe atiborrarse a los estudiantes con fechas (nacimiento y muerte de tal héroe; fecha de fundación de tal ciudad; fecha de tal descubrimiento, etc.), pero no debe olvidarse que la Historia se desarrolla en el tiempo, que se ocupa del pasado (aunque sea inmediato) y que algunas referencias temporales, algunas coordenadas del tiempo son indispensables. por ejemplo, puede no saberse la fecha de nacimiento y muerte de todos los presidentes de Colombia, o de cada una de las batallas de la independencia, pero no puede olvidarse que las reformas políticas y sociales de José Hilario López fueron hacia 1850, es decir, en la segunda mitad del siglo XIX; ni que Núñez y Caro vivieron hacia el final del mismo siglo, ni que Rufino J. Cuervo, no vivió en el siglo XVIII, en la época colonial, sino a fines del pasado siglo y comienzos del presente en plena era republicana. $Y$ en la Historia Universal no puede creerse que la Revolución Francesa o la independencia de los Estados Unidos fueron en el siglo pasado, o en el XV. La Historia Universal, como la Nacional está dividida en ciclos o coyunturas, identificables con ciertas fechas, relativamente convencionales, pero no arbitrarias y tales fechas, globales al menos, deben ser tenidas presentes. Por ejemplo, es claro que en la Historia de Colombia se pueden identificar las siguientes coyunturas o ciclos de su historia: El descubrimiento y conquista (1510-1550). La colonización y la formación de la sociedad colonial (1550-1810). La independencia (1810-1830). La disolución de la Gran Colombia. La República de Nueva Granada (18321850). Los hechos a partir de 1850 tienen contornos cíclicos claros que corresponden a reformas y cambios significativos: 1850-1860 Reformas de López, formación de Partidos, las influencias románticas francesas. 1860-1886 guerra del 60, Constitución federal del 63. Reformas de Mosquera. Federalismo. 1886-1900 Reforma Constitucional del 86. Obra de Núñez y Caro. Guerra de los mil días.

Aparición del café como primer producto de exportación de Colombia. Separación de Panamá. 1900-1930 Décadas bien caracterizadas por muchos hechos: Ingreso del país al desarrollo industrial, gobierno y dictadura de Reyes, Movimiento Republicano, Indemnización Americana, Reformas de Pedro N. Ospina, Cambio político y crisis económica de 1930. 1930-1946 Sucesión de gobiernos liberales, Reformas de López Pumarejo (1935-1936). Segunda Guerra Mundial. Arranque hacia la industrialización. Cambios demográficos. Violencia e inestabilidad política. Problemas sociales urbanos y agrarios bien caracterizados.

Una cronología de esta naturaleza debe ser comprendida y retenida por el estudioso de la Historia. Algo semejante ocurre con la Historia Universal.

d)El profesor de Historia debe tener un buen acervo de anécdotas y datos biográficos. No debe entenderse esto como un regreso a la historia anecdótica y hecha en torno de las personalidades históricas. Pero debe tenerse en cuenta que el programa (como la historia en general) no prescinde de ciertas personalidades que han desempeñado un importante papel en la historia como legisladores, hombres de estado, militares, intelectuales o fundadores de empresas. Una buena anécdota puede hacer comprender una personalidad y además ameniza incidentalmente la enseñanza. 
e)El profesor de Historia debe poseer una mínima capacidad de dibujante. Un buen esquema, un croquis, un diagrama bien hecho son elementos insustituibles de una buena enseñanza.

f) Debe también saber utilizar otros recursos didácticos que despierten interés y participación en el alumno. No sólo debe desarrollar su clase preguntando y dialogando con el alumno (hay' que terminar con la clase monólogo y con el discurso), sino que debe utilizar modernos materiales didácticos como películas, transparencias, láminas, mapas, etc. Si no posee éstos, siempre tendrá a la mano prensa o revistas. Extractar las noticias del día y ponerlas en periódicos murales, permitirá ir de la actualidad al pasado y explicar la historia y la vida social contemporánea, llena de interrelaciones entre unos países y otros. También deberá recurrirse a las mesas redondas, las discusiones organizadas y otras formas similares de participación del alumno.

g) Finalmente el profesor de historia (como en general el de Ciencias Sociales) debe tener un espíritu abierto, libre y realista. No puede ni debe ser propagandista, ni apóstol. de esta o aquella idea. Debe exponer los hechos y conocimientos con objetividad y dejar desenvolver libre y espontáneo el criterio del alumno en aquellas materias susceptibles de aceptar puntos de vista diferentes o alternativos. No puede tampoco convertirse en detractor o defensor de una personalidad histórica, de una época o de una forma de vida o de cultura. El saber histórico auténtico conduce a comprender que cada época tiene sus tareas y posibilidades de desarrollo, que cada personalidad actúa en circunstancias particulares y en papeles diferentes. No puede exigirse a un político que actúe como intelectual o un moralista, ni a un militar que dirige una guerra como un profesor de jurisprudencia. Cada actividad tiene su lógica, sus condiciones de actuación y exige de los actores cierto tipo de conducta.

Tampoco debe efectuar discriminaciones nacionales, radicales, religiosas, para condenar o dar más valor a unos documentos o unos historiadores o a unos libros que a otros. En esto debe atenerse a las normas del método científico. Debe analizar el material formulándose preguntas como estas: ¿Documenta bien sus afirmaciones este autor? ¿Analiza los hechos con lógica? ¿Está bien informado? ¿Posee cualidades de claridad en la exposición?. etc.

Estas mismas cualidades son las que deben guiar su enseñanza. El profesor que logra hacer ver a sus alumnos que el juicio histórico no es arbitrario, ni puede ser algo de sentimiento personal, sino que debe apoyarse en conocimientos ciertos y en reglas de análisis objetivas, habrá logrado transmitir no sólo conocimientos, sino hábitos de pensar correctos y además un sentido de responsabilidad intelectual y moral que son las mejores metas de cualquier enseñanza. En este mismo orden de ideas el profesor debe tener en cuenta que la Historia es un saber complejo y siempre incompleto. Que lo que hoy se conoce hasta cierto límite, puede conocerse mejor mañana cuando la investigación haya progresado; que el juicio de hoy, puede rectificarse posteriormente a la luz de conocimientos nuevos. Por lo demás esto ocurre en todo el saber y en todas las ciencias. Por razones de esta índole tampoco debe vacilar en declarar su ignorancia de algún tema, o su conocimiento limitado de él. No debe olvidarse que para el profesor y para el alumno es más importante saber pensar, buscar e investigar que saber muchas cosas o acumular muchos conocimientos. 
La enseñanza y la comprensión de la historia no puede aislarse de la geografía. Los hombres de una época o de un país hacen la historia dentro de un medio geográfico que les presenta o grandes facilidades para conseguir sus objetivos y desarrollarse o grandes obstáculos y a veces limitaciones invencibles. Los distintos factores que componen la geografía en que actúa un grupo humano (clima, fertilidad del suelo, relieve, ubicación geográfica relativa) influyen en el desarrollo de la riqueza, en las costumbres, en el carácter, en las circunstancias históricas. Es un hecho innegable que las condiciones del hábitat geográfico han conformado muchos aspectos de la vida histórica y de la personalidad de culturas y pueblos. Desarrollarse en llanuras o en montañas, en territorios que tengan costas marítimas o carezcan de ellas; en climas templados estacionales o en climas tropicales húmedos; en territorios ricos en recursos naturales (vegetales, mineros, hidráulicos) o en zonas desérticas, es algo que debe tener influencia sobre la historia de un grupo.

Pero de esta hipótesis no podemos concluir que la historia es determinada por la geografía o que por la geografía podemos explicar la historia. En líneas generales podemos aceptar que sin la geografía no podemos explicar muchos hechos históricos, pero que ningún hecho histórico se explica sólo por la geografía. Como en general no se explica en términos de un solo Factor, cualesquiera que sea.

Correlaciones de la historia con la geografía son necesarias hasta el punto de poderse enseñar simultáneamente. Para no incidir en repeticiones y para estar más de acuerdo con la realidad y con la lógica, la geografía se enseñará como geografía histórica. En efecto, la geografía como medio en que se desarrolla la acción del hombre tiene una historia, porque ésta la transforma. Desde luego algunos factores como los físicos permanecerán más o menos constantes y otros cambian a un ritmo acelerado. El clima y el relieve son los más estáticos, aunque no en términos absolutos. En cambio los elementos económicos, humanos y sociales, aun los tipos de paisajes cambian históricamente. La geografía económica, comercial y humana (producción, transporte, cambios demográficos) tiene un cambio muy dinámico, hasta el punto de que podemos hablar de una geografía en el siglo XV, en el XVIII, en el XIX y en el XX. El esquema adjunto señala los temas históricos-geográficos que dan contenido a la correlación anotada (véase anexo 1).

Anexo 1

Correlación con la geografía

\begin{tabular}{|l|l|l|}
\hline $\begin{array}{l}\text { Historia de } \\
\text { Colombia Historia } \\
\text { Universal }\end{array}$ & Geografía de Colombia & Temas de Geografía Universal \\
\hline $\begin{array}{l}\text { I. Aborígenes Hacia } \\
\mathbf{1 5 5 0}\end{array}$ & $\begin{array}{l}\text { Climas, paisajes, recursos naturales, } \\
\text { hidrografía de Chibchas, Quimbayas, } \\
\text { Taironas: Sabana de Bogotá. Clima } \\
\text { medio húmedo del Quindío (oro. sal y yas: Altiplano seco de México. Mayas: } \\
\text { ríos de la región). Sierra Nevada de } \\
\text { Santa Marta. }\end{array}$ & $\begin{array}{l}\text { Sucatán. Incas: Sierra seca peruana. } \\
\text { España Septentrional, Alemania Central }\end{array}$ \\
\hline $\begin{array}{l}\text { II. Conquista } \\
\mathbf{1 5 0 0 - 1 5 5 0}\end{array}$ & $\begin{array}{l}\text { Las costas (Atlántica) donde se hicieron } \\
\text { las primeras fundaciones. El Río } \\
\text { Magdalena como vía de penetración. La }\end{array}$ & $\begin{array}{l}\text { Geografía de España. Función de sus ríos } \\
\text { y puertos en la emigración a América: El } \\
\text { Guadalquivir, Sevilla, Cádiz. Climas y y }\end{array}$ \\
\hline
\end{tabular}




\begin{tabular}{|c|c|c|}
\hline & selva como obstáculo al poblamiento. & $\begin{array}{l}\text { paisajes de la península y sus analogías } \\
\text { con los americanos. Regiones: Castilla, } \\
\text { Andalucía, Extremadura. }\end{array}$ \\
\hline $\begin{array}{l}\text { III. Colonia } \\
1550-1810\end{array}$ & $\begin{array}{l}\text { Los altiplanos (Sabana\} y los centros } \\
\text { mineros (Antioquia) como centros de } \\
\text { asentamiento: clima, hidrografía, } \\
\text { recursos naturales. Ríos y puertos como } \\
\text { vehículos de colonización: Santa Marta. } \\
\text { Cartagena; el Magdalena, el Carare, el } \\
\text { Atrato, el San Juan, el Cauca, etc. }\end{array}$ & \\
\hline $\begin{array}{l}\text { IV. República } \\
\text { a. } 1810-1850\end{array}$ & $\begin{array}{l}\text { Geografía comercial, económica, social } \\
\text { del Colombia, a partir del Siglo XIX. } \\
\text { Los transportes la integración del } \\
\text { territorio nacional. Los ferrocarriles. } \\
\text { Geografía del oro, el tabaco, la quina y } \\
\text { el café. } \\
\\
\text { Geografía de las colonizaciones. El } \\
\text { occidente colombiano (colonización } \\
\text { antioqueña). Colonizaciones del } \\
\text { Magdalena y vertientes occidentales de } \\
\text { la Cordillera Oriental, la conquista de los } \\
\text { Llanos Orientales: clima, hidrografía, } \\
\text { relieve, demografía, economía de estas } \\
\text { regiones. }\end{array}$ & $\begin{array}{l}\text { Geografía de la revolución industrial en } \\
\text { Europa y los Estados Unidos. Los } \\
\text { transportes. El vapor. las grandes arterias } \\
\text { hidrográficas. Geografía del carbón y el } \\
\text { hierro. Ventajas climáticas y recursos } \\
\text { naturales de naciones como Inglaterra, } \\
\text { Francia, Alemania, Estados Unidos y } \\
\text { Rusia. Distribución geográfica de los } \\
\text { grandes recursos naturales y de } \\
\text { tecnología en el siglo XIX. }\end{array}$ \\
\hline b. $1850-1950$ & $\begin{array}{l}\text { La geografía industrial (urbana), agrícola } \\
\text { (rural y demográfica de Colombia en el } \\
\text { presente siglo. Distribución geográfica } \\
\text { de la población. Cambios en la estructu- } \\
\text { ra de ésta. El desarrollo urbano. Los } \\
\text { grandes núcleos: Bogotá, Medellín, Cali, } \\
\text { Barranquilla. Geografía de los nuevos } \\
\text { cultivos: algodón, arroz, azúcar. } \\
\text { Geografía de las nuevas formas de } \\
\text { agricultura comercial e industrializada. } \\
\text { Valledupar, las Sabanas de Bolívar. El } \\
\text { Valle del Cauca. El Magdalena Medio. } \\
\text { Magdalena Huilense (Tolimense). } \\
\text { Geografía ganadera. Geografía } \\
\text { industrial. Acentuar las características } \\
\text { regionales. }\end{array}$ & $\begin{array}{l}\text { Geografía universal en el siglo XX. Los } \\
\text { grandes núcleos continentales: Estados } \\
\text { Unidos, Europa Occidental (Inglaterra, } \\
\text { Francia, Alemania, Europa Central. El } \\
\text { Mediterráneo (Italia, España). Rusia. Asia } \\
\text { (Japón y China). Africa. Como conjunto } \\
\text { Indonesia. Se acentuará la geografía } \\
\text { económica, comercial y humana. Se } \\
\text { destacarán ciertos factores como } \\
\text { desarrollo industrial, tecnológico. Nuevos } \\
\text { sistemas de comunicaciones (aviación, } \\
\text { radio, televisión. Etc. ) y su influencia en } \\
\text { las interrelaciones de los países, } \\
\text { transformaciones de las distancias, de la } \\
\text { posición geográfica relativa y de los } \\
\text { núcleos de influencia económica-política. }\end{array}$ \\
\hline
\end{tabular}

\section{Anexo 2}

Esquema de discusión para los programas de Icolpe. Ciclos intensivos para las diferencias de edades

\begin{tabular}{|c|c|c|c|}
\hline & $\begin{array}{c}7-10 \text { años } \\
\text { Colombia: Conquista } \\
y \text { Colonia }\end{array}$ & Historia Universal & Ciencia Social \\
\hline 1 Semestre & $\begin{array}{l}\text { 1. Los aborígenes. Tribus } \\
\text { Locales. Referencias, para } \\
\text { la comparación a Chibchas, }\end{array}$ & $\begin{array}{l}\text { Referencia. para comparación, } \\
\text { a época prehistórica y a tribus } \\
\text { actuales. Otras culturas }\end{array}$ & $\begin{array}{l}\text { Casa - familia } \\
\text { Aldea - Ciudad }\end{array}$ \\
\hline
\end{tabular}




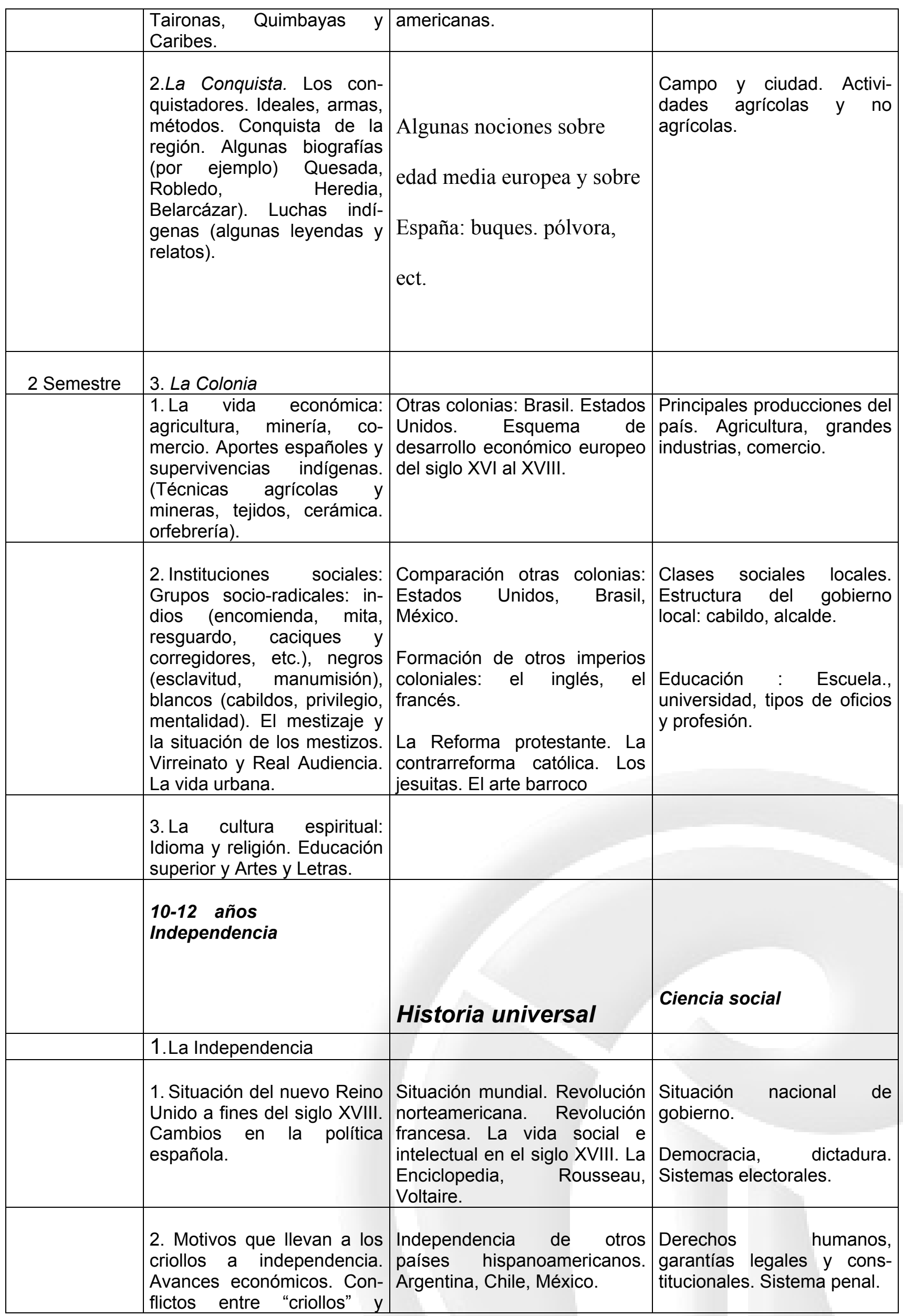




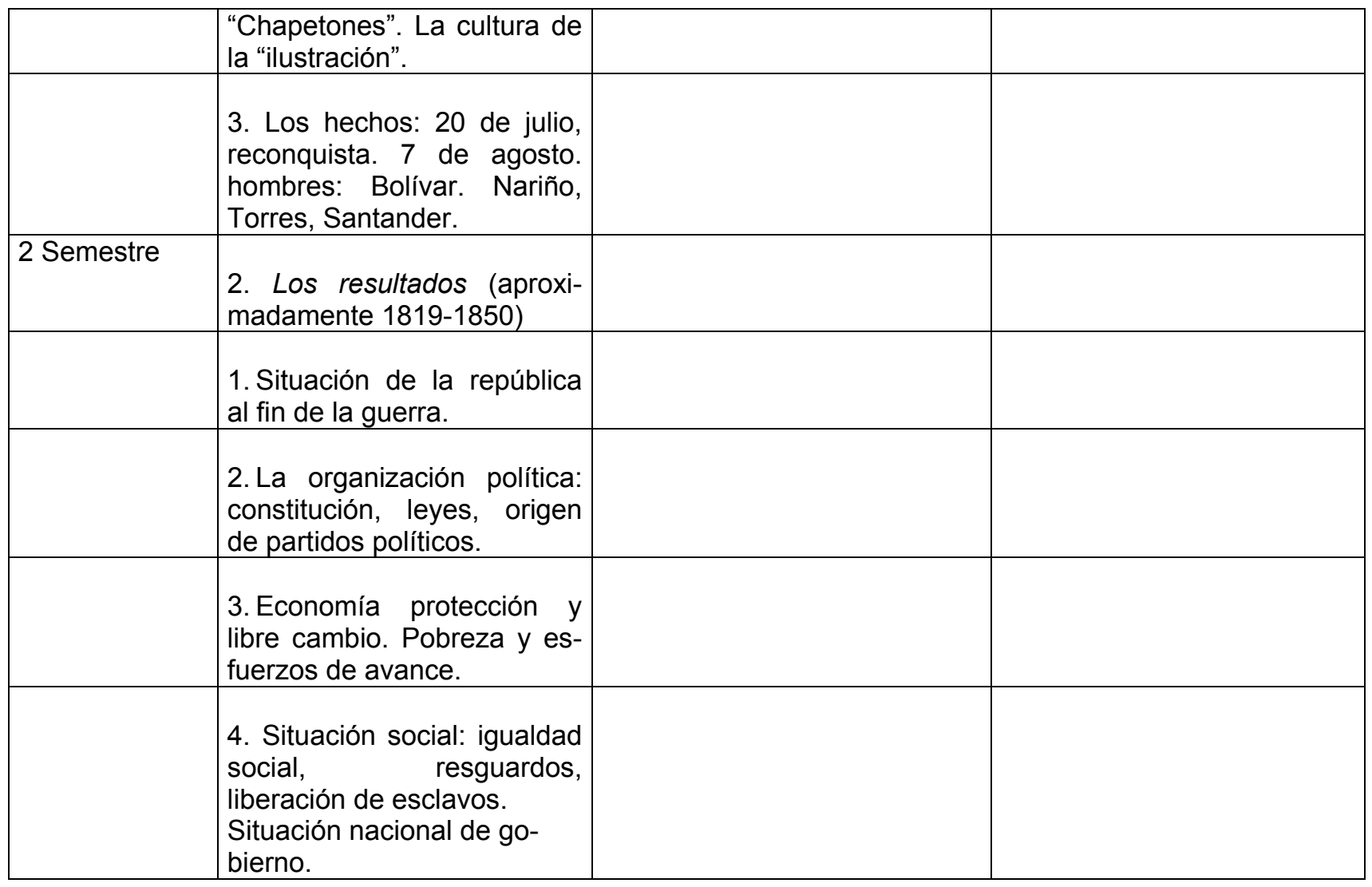

\begin{tabular}{|c|c|c|c|}
\hline & $\begin{array}{l}\text { 12-14 años } \\
\text { Colombia moderna } \\
\text { (Aprox. 1850-1930) }\end{array}$ & Historia Universal & Ciencia Social \\
\hline \multirow[t]{3}{*}{1 Semestre } & $\begin{array}{l}\text { 1. Inestabilidad social y } \\
\text { política. Guerras civiles } \\
\text { (por ejemplo } 1861,1899 \text { ). } \\
\text { Constitución del } 63 \text { y } 86 .\end{array}$ & $\begin{array}{l}\text { Siglo XIX. en algunos } \\
\text { aspectos comparables: } \\
\text { agitación social. } \\
\text { revoluciones de } 1830 \text { y } \\
\text { 1848. nacionalismo. } \\
\end{array}$ & $\begin{array}{l}\text { Discusión sobre pro- } \\
\text { blemas como situación } \\
\text { del café. Precios y } \\
\text { salarios. }\end{array}$ \\
\hline & $\begin{array}{l}\text { 2.El desarrollo económi- } \\
\text { co: } \\
\text { A. El comercio de } \\
\text { exportación: oro, tabaco, } \\
\text { quina, añil. } \\
\text { B. Crisis de las arte- } \\
\text { sanías. Intentos de indus- } \\
\text { trialización. } \\
\text { C. Transportes. Navega- } \\
\text { ción, ferrocarriles. Cami- } \\
\text { nos. } \\
\text { D.Empresarios } \\
\text { capitales extranjeros. y }\end{array}$ & 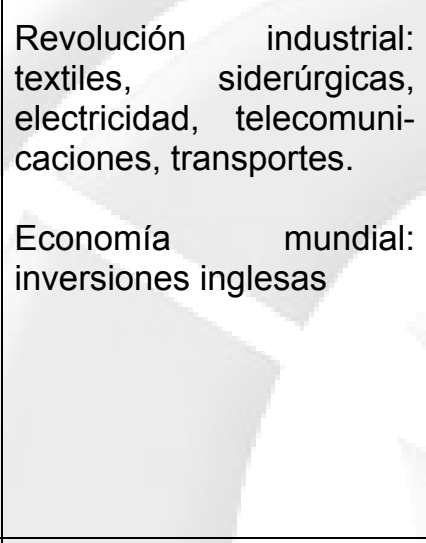 & $\begin{array}{l}\text { Entidades estatales liga- } \\
\text { das a la economía. } \\
\text { Bancos. } \\
\text { Colonizaciones y situa- } \\
\text { ción agraria. }\end{array}$ \\
\hline & $\begin{array}{l}\text { 3. La expansión del po- } \\
\text { blamiento. } \\
\text { A. "Colonización } \\
\text { antioqueña". } \\
\text { B. Otras colonizaciones. } \\
\text { (asentar aquí la coloniza- } \\
\text { ción regional). }\end{array}$ & $\begin{array}{l}\text { La cuestión social } \\
\text { moderna. Aparición de } \\
\text { los sindicatos. El } \\
\text { socialismo. La imprenta y } \\
\text { la } \\
\text { prensa. } \\
\text { La literatura romántica. }\end{array}$ & \\
\hline
\end{tabular}




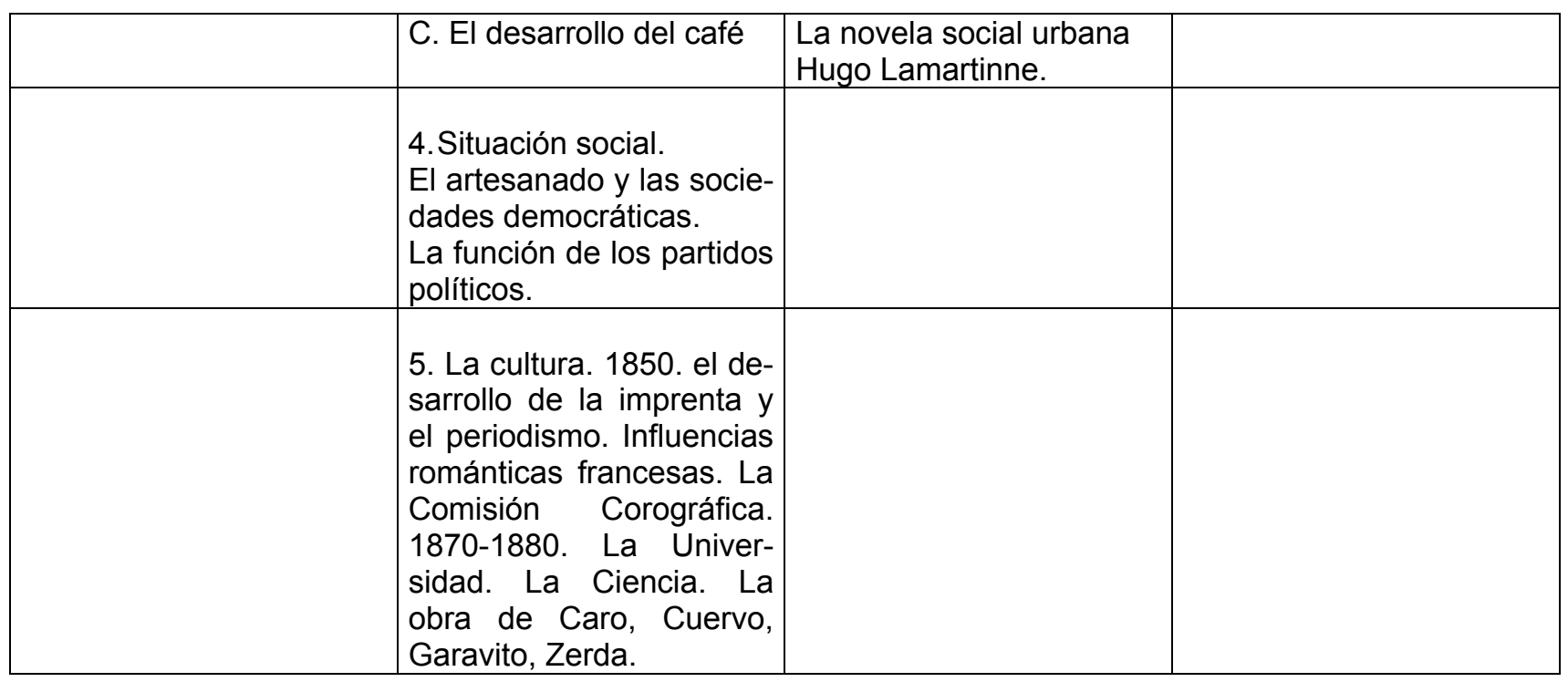

\begin{tabular}{|c|c|c|c|}
\hline & $\begin{array}{c}\text { 14-16 años } \\
\text { Colombia } \\
\text { contemporánea } \\
\text { (1930 en adelante) } \\
\end{array}$ & Historia Universal & Ciencia Social \\
\hline \multirow[t]{5}{*}{2 Semestre } & $\begin{array}{l}\text { 1. La crisis del 29. Sus } \\
\text { repercu-siones. El } \\
\text { liberalismo. Desarrollo } \\
\text { sindical. } \\
\text { 2. Las reformas de 1936. } \\
\text { Reformas constituciona- } \\
\text { les. Sistemas tributarios. } \\
\text { Apoyo al sindicalismo. }\end{array}$ & $\begin{array}{l}\text { Estados Unidos: su de- } \\
\text { sarrollo económico. La } \\
\text { emigración europea a } \\
\text { América. Su importancia. } \\
\text { Algunos antecedentes de } \\
\text { su papel mundial. } \\
\text { (Guerra (de México, gue- } \\
\text { rra con España). }\end{array}$ & $\begin{array}{l}\text { Sindicalismo y problemas } \\
\text { laborales. } \\
\text { Asociaciones gremiales. } \\
\text { Urbanización. } \\
\text { Migraciones, desempleo. }\end{array}$ \\
\hline & $\begin{array}{l}\text { 3.Urbanización y desarro- } \\
\text { llo de industria. } \\
\text { 4. La segunda guerra } \\
\text { mundial. Repercusiones } \\
\text { en el país. }\end{array}$ & $\begin{array}{l}\text { El enfrentamiento } \\
\text { Estados Unidos, Unión } \\
\text { Soviética. Guerra fría y } \\
\text { revoluciones. Descolon- } \\
\text { ización. Despertar del } \\
\text { tercer mundo. }\end{array}$ & $\begin{array}{l}\text { La economía actual: } \\
\text { industria, relaciones con } \\
\text { metrópolis industriales. } \\
\text { Sistema político, partidos, } \\
\text { estructura del estado. }\end{array}$ \\
\hline & $\begin{array}{lr}\text { 5. El período } & 1946-1957 . \\
\text { Violencia } & \text { y } \text { crisis } \\
\text { democrática. } & \text { Dictadura } \\
\text { militar. } & \end{array}$ & & \\
\hline & $\begin{array}{l}\text { 6. De } 1957 \text { al presente: } \\
\text { reformas constituciona- } \\
\text { les, Frente Nacional. } \\
\text { Anapo. }\end{array}$ & & \\
\hline & $\begin{array}{l}\text { 7. Problemas económicos } \\
\text { y sociales: reforma } \\
\text { agraria, desarrollo econó- }\end{array}$ & & \\
\hline
\end{tabular}


mico, el café y los ciclos

de la economía. Inversión

extranjera.

Desempleo.

Educación.

\section{Anexo 3 \\ Esquema de discusión \\ Ciclo completo para 7-10 anos}

\begin{tabular}{|c|c|c|c|}
\hline & Historia de Colombia & Historia Universal & Ciencia Social \\
\hline \multirow[t]{3}{*}{1 Semestre } & Conquista (1510-1550) & & \\
\hline & $\begin{array}{l}\text { I.Los aborígenes: Tribus } \\
\text { locales. Referencias } \\
\text { compa-rativas } \quad \text { con } \\
\text { chibchas. Taironas. } \\
\text { Quimbayas. Caribes. } \\
\end{array}$ & $\begin{array}{l}\text { Referencia. } \\
\text { comparación, a época } \\
\text { prehistórica y a tribus } \\
\text { actuales. Otras culturas } \\
\text { americanas. }\end{array}$ & \\
\hline & $\begin{array}{l}\text { La Conquista. Los } \\
\text { conquistadores. Ideales, } \\
\text { armas, métodos de } \\
\text { conquista. Algunas } \\
\text { biografías: Quesada, Ro- } \\
\text { bledo. etc. Referencia al } \\
\text { conquistador de la región. } \\
\text { Resistencia ‘y luchas } \\
\text { indígenas. Fundación de } \\
\text { ciudades. }\end{array}$ & $\begin{array}{l}\text { Algunas nociones sobre } \\
\text { edad media europea y } \\
\text { sobre España: buques, } \\
\text { pólvora. etc. }\end{array}$ & \\
\hline \multirow[t]{4}{*}{2 Semestre } & $\begin{array}{l}\text { II. La Colonia (1550- } \\
\text { 1810) }\end{array}$ & & \\
\hline & $\begin{array}{l}\text { Instituciones sociales y } \\
\text { políticas. El proceso de } \\
\text { poblamiento y mestizaje. } \\
\text { La destrucción de la } \\
\text { población indígena. }\end{array}$ & $\begin{array}{l}\text { Otras colonias: Brasil, } \\
\text { Estados Unidos. Esque- } \\
\text { ma de desarrollo } \\
\text { económico del siglo XVI } \\
\text { al XVIII. }\end{array}$ & $\begin{array}{l}\text { Principales productores } \\
\text { del país Agricultura. } \\
\text { grandes industrias, co- } \\
\text { mercio. }\end{array}$ \\
\hline & $\begin{array}{l}\text { Grupos sociales. } \\
\text { Indígenas, españoles, } \\
\text { mestizos, criollos y } \\
\text { negros esclavos. La } \\
\text { encomienda - La mitad. } \\
\text { La esclavitud negra. La } \\
\text { situación, privilegios y } \\
\text { discriminaciones que } \\
\text { afectaron al mestizo, al } \\
\text { criollo y al español. } \\
\text { Administración: Real } \\
\text { Audiencia y Cabildos. }\end{array}$ & $\begin{array}{l}\text { Comparación otras colo- } \\
\text { nias: Estados Unidos, } \\
\text { Brasil, México. } \\
\text { Formación de otros } \\
\text { imperios coloniales: El in- } \\
\text { glés y el francés. } \\
\text { La reforma protestante. } \\
\text { La contrarreforma } \\
\text { católica. Los jesuitas. El } \\
\text { arte barroco. }\end{array}$ & $\begin{array}{l}\text { Clases sociales locales. } \\
\text { Estructura dcl gobierno } \\
\text { local: cabildo, alcalde. } \\
\text { Educación: escuela, } \\
\begin{array}{l}\text { Universidad, tipos de } \\
\text { oficio y profesión. }\end{array}\end{array}$ \\
\hline & $\begin{array}{l}\text { la vida económica: } \\
\text { Minería, agricultura, } \\
\text { ganadería. Comercio. }\end{array}$ & & \\
\hline & Principales zonas de pro- & & \\
\hline
\end{tabular}




\begin{tabular}{|c|c|c|c|}
\hline & 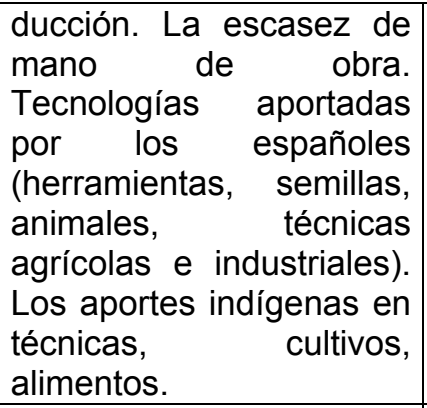 & & \\
\hline & 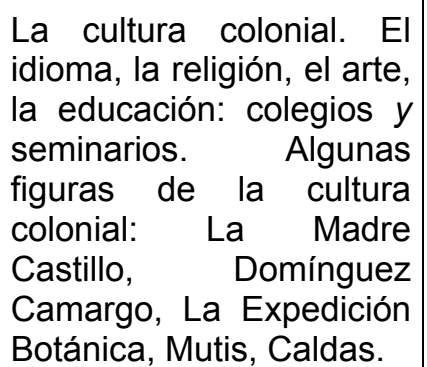 & & \\
\hline 3 Semestre & 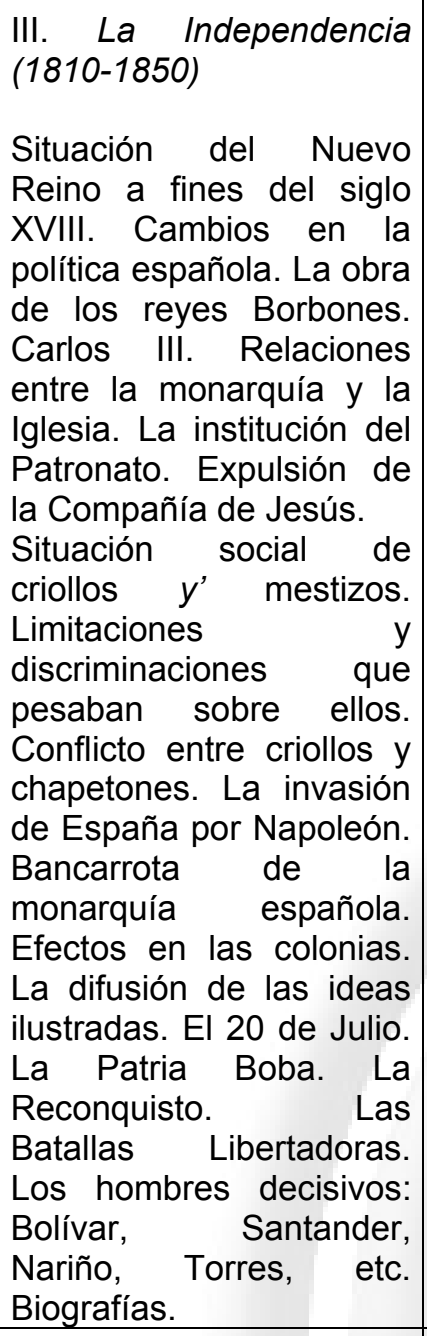 & $\begin{array}{l}\text { Situación mundial. Re- } \\
\text { volución norteamericana. } \\
\text { Revolución francesa. La } \\
\text { vida social e intelectual } \\
\text { en el siglo XVIII. La } \\
\text { enciclopedia, Rousseau } \\
\text { Voltaire } \\
\text { Independencia de otros } \\
\text { países hispanoamerica- } \\
\text { nos. Argentina, chile, } \\
\text { México. }\end{array}$ & 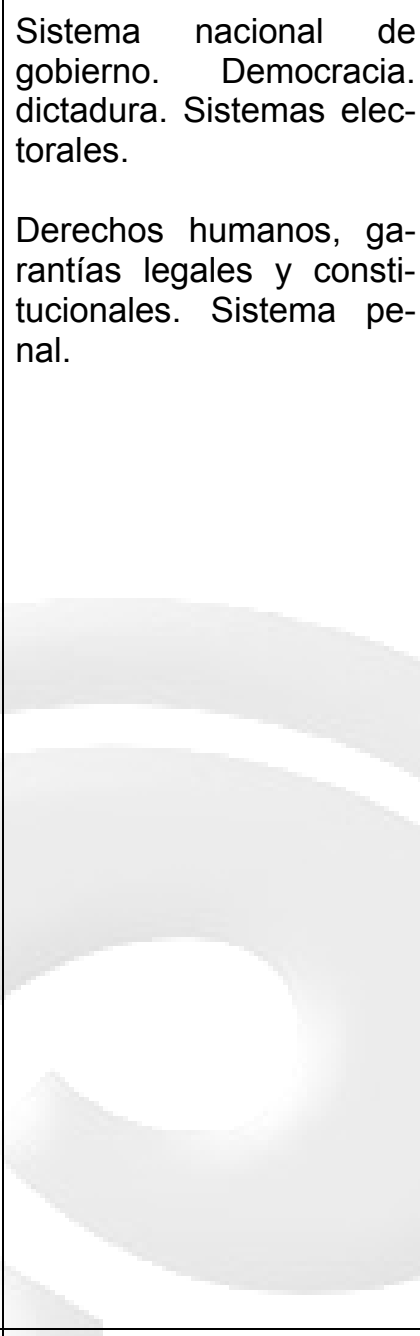 \\
\hline \multicolumn{4}{|l|}{4 Semestre } \\
\hline & $\begin{array}{l}\text { Destrucción de bienes y } \\
\text { desorganización } \\
\text { administrativa }\end{array}$ & $\begin{array}{l}\text { Revolución industrial en } \\
\text { Europa. Expansión co- } \\
\text { lonial de las potencias } \\
\text { europeas. El imperialis- } \\
\text { mo. Hegemonía inglesa. } \\
\text { Inglaterra en América. }\end{array}$ & $\begin{array}{l}\text { Diferencias entre indus- } \\
\text { tria (fábrica) } \\
\text { manufactura (artesanía). } \\
\text { Importancia de la } \\
\text { industria en el desarrollo } \\
\text { de un país. Problema }\end{array}$ \\
\hline
\end{tabular}




\begin{tabular}{|c|c|c|c|}
\hline & $\begin{array}{l}\text { Constitución de Cúcuta. } \\
\text { Principales aspectos de } \\
\text { ésta (Derechos y deberes } \\
\text { del ciudadano, } \\
\text { disposiciones sobre el } \\
\text { presidente y' el Con- } \\
\text { greso). Diversas } \\
\text { corrientes de opinión que } \\
\text { se presentaron. } \\
\end{array}$ & & $\begin{array}{l}\text { social obrero en la } \\
\text { sociedad industrial. } \\
\text { Importancia del comercio } \\
\text { exterior (importaciones y } \\
\text { exportaciones) en el } \\
\text { desarrollo económico y } \\
\text { social. }\end{array}$ \\
\hline & $\begin{array}{l}\text { Reformas Políticas y } \\
\text { sociales: } \\
\text { Igualdad política, elimina- } \\
\text { ción de fueros y } \\
\text { privilegios legales. } \\
\text { Libertad de esclavos. } \\
\text { Eliminación del tributo } \\
\text { indígena. Disolución de } \\
\text { resguardos de indios. }\end{array}$ & & \\
\hline & $\begin{array}{l}\text { Reformas económicas: } \\
\text { Eliminación de } \\
\text { impuestos. Libertad de } \\
\text { comercio. Contactos } \\
\text { comerciales con varías } \\
\text { naciones (Inglaterra, } \\
\text { Estados Unidos, Francia). }\end{array}$ & & \\
\hline & $\begin{array}{l}\text { Disolución de la Gran } \\
\text { Colombia: } \\
\text { Sus causas. Adminis- } \\
\text { traciones Neogranadinas } \\
\text { de Santander. Márquez, } \\
\text { Mosquera. Principales } \\
\text { hechos. Reformas polí- } \\
\text { ticas y sociales }\end{array}$ & & \\
\hline 5 Semestre & $\begin{array}{l}\text { V. La República en la } \\
\text { segunda mitad del siglo } \\
\text { XIX (1850-1869) } \\
\text { inestabilidad política y so- } \\
\text { cial. Las reformas } \\
\text { políticas. } \\
\text { Económicas y sociales de } \\
\text { José Hilario López. La } \\
\text { libertad de los esclavos. } \\
\text { Eliminación de } \\
\text { monopolios. El tabaco y } \\
\text { su desarrollo posterior. } \\
\text { Constitución de 1851. } \\
\text { Las influencias del } \\
\text { romanticismo social y } \\
\text { político de Francia (Revo- } \\
\text { lución de 1848). Las } \\
\text { socie-dades democrá- } \\
\text { ticas y la situación de los } \\
\text { artesanos. La cultura. La } \\
\text { comisión Corográfica. El } \\
\text { desarrollo de la prensa y } \\
\text { la imprenta. La formación } \\
\text { de los partidos políticos. }\end{array}$ & $\begin{array}{l}\text { Siglo XIX, en algunos } \\
\text { aspectos comparables: } \\
\text { agitación social, revolu- } \\
\text { ciones de } 1830 \text { y } 1848 . \\
\text { nacionalismos. } \\
\text { Revolución industrial: } \\
\text { textiles, siderúrgicas, } \\
\text { electricidad, telecomu- } \\
\text { nicaciones, transportes. } \\
\text { Economía mundial: in- } \\
\text { versiones inglesas. } \\
\text { La cuestión social } \\
\text { moderna. Aparición de } \\
\text { los sindicatos. EI } \\
\text { socialismo. La imprenta y } \\
\text { la prensa. La literatura } \\
\text { romántica. La novela } \\
\text { social urbana. Hugo, } \\
\text { Lamartine, Sué. }\end{array}$ & $\begin{array}{l}\text { Discusión sobre proble- } \\
\text { mas como situación del } \\
\text { café. Precios y salarios. } \\
\text { Entidades estatales Li- } \\
\text { gadas a la economía. } \\
\text { Bancos. } \\
\begin{array}{l}\text { Colonizaciones y situa- } \\
\text { ción agraria. }\end{array}\end{array}$ \\
\hline
\end{tabular}




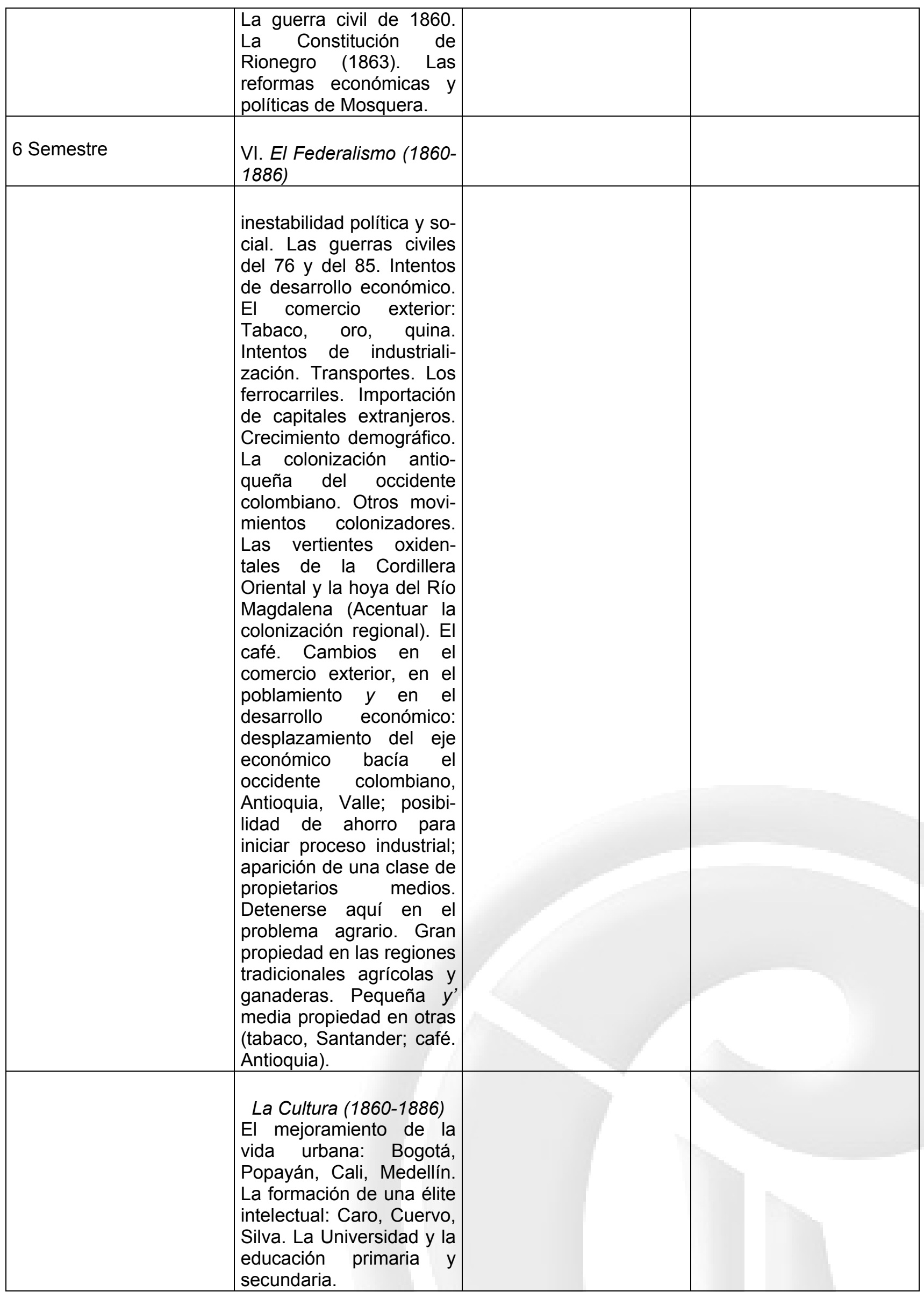




\begin{tabular}{|c|c|c|c|}
\hline 7 Semestre & $\begin{array}{l}\text { VII La República Unitaria } \\
\text { (1886-1930) } \\
\text { El fin del período federal. } \\
\text { La Constitución de 1886, } \\
\text { sus principales caracte- } \\
\text { rísticas. La obra de } \\
\text { Núñez y Caro. La guerra } \\
\text { de los mil días. La } \\
\text { pérdida de Panamá. Paz } \\
\text { y reconstrucción. Gobie- } \\
\text { rno de Reyes. El desa- } \\
\text { rrollo económico de 1910 } \\
\text { a 1930. Las reformas } \\
\text { administrativas de Pedro } \\
\text { N. Ospina. La aparición } \\
\text { del movimiento sindical y } \\
\text { los modernos conflictos } \\
\text { sociales. La crisis de } \\
\text { 1929-1939. La situación } \\
\text { social y económica du- } \\
\text { rante la depresión. }\end{array}$ & $\begin{array}{l}\text { Estados Unidos: su } \\
\text { desarrollo económico. La } \\
\text { emigración europea a } \\
\text { América. Su importancia. } \\
\text { Algunos antecedentes de } \\
\text { su papel mundial. } \\
\text { (Guerra de México. gue- } \\
\text { rra con España). } \\
\text { El enfrentamiento Esta- } \\
\text { dos Unidos - Unión } \\
\text { Soviética. Guerra fría y } \\
\text { revoluciones. Descolo- } \\
\text { nización. Despertar del } \\
\text { tercer mundo. }\end{array}$ & $\begin{array}{l}\text { Sindicalismo Y problemas } \\
\text { laborales. } \\
\text { Asociaciones gremiales. } \\
\text { 1. Urbanización, Migra- } \\
\text { ciones, desempleo. } \\
\text { La economía actual in- } \\
\text { dustria, relaciones con } \\
\text { metrópolis industriales. } \\
\text { Sistema político, partidos, } \\
\text { estructura del estado. }\end{array}$ \\
\hline \multirow[t]{2}{*}{8 Semestre } & $\begin{array}{l}\text { VIII. La Co/ombia con- } \\
\text { temporanea }\end{array}$ & & \\
\hline & $\begin{array}{l}\text { La superación de la crisis } \\
\text { de 1930. El cambio } \\
\text { político. El Gobierno de la } \\
\text { Concentración Nacional } \\
\text { Olaya Herrera. La } \\
\text { primera administración } \\
\text { López y sus reformas: } \\
\text { reforma constitucional, } \\
\text { reforma fiscal y tributaria, } \\
\text { reforma educativa. Los } \\
\text { efectos de la segunda } \\
\text { guerra mundial sobre la } \\
\text { economía nacional. El } \\
\text { desarrollo industrial de } \\
\text { 1940-1950. Los cambios } \\
\text { demográficos. } \\
\text { Crecimientos de las } \\
\text { ciudades. Emigración del } \\
\text { campo de las ciudades. } \\
\text { Nuevas tareas sociales; } \\
\text { reforma agraria, reforma } \\
\text { educativa, la cultura y la } \\
\text { educación de 1950-1970. } \\
\text { Las universidades. La } \\
\text { plástica. La literatura en } \\
\text { el período reciente. }\end{array}$ & & \\
\hline
\end{tabular}




\title{
GUÍA BIBLIOGRÁFICA PARA EL DESARROLLO DE LOS PROGRAMAS
}

\author{
I. Revistas
}

Boletín de Historia y Antigüedades. Academia Colombiana de Historia.

Revista Colombiana de Antropología. Publicada por el Instituto Colombiano de Antropología (para la Etnohistoria de Colombia, Etnología, Etnografía, Antropología).

Anuario Colombiano de Historia Social /y de la Cultura. Publicado por el Departamento de

Historia de la Universidad Nacional (para la Historia Social y de la Cultura).

Thesaurus. Boletín del Instituto Caro y Cuervo (para la Historia de la Cultura, particularmente la Literatura).

Archivos. Publicación de la Academia Colombina de Historia.

\section{Bibliografías}

Giraldo Jaramillo, Gabriel. Bibliografía Colombiana de Viajes. Biblioteca de Bibliografía Colombiana. Bogotá: Editorial ABC, 1957.

Giraldo Jaramillo, Gabriel. Bibliografía de Bibliografías Colombianas. Segunda edición corregida y puesta al día por Rubén Pérez Ortiz. Instituto Caro y Cuervo. Serie Bibliografías. Bogotá: Imprenta Patriótica del Instituto Caro y Cuervo, 1960.

Ortega Ricaurte, Enrique. Bibliografía Académica, Bogotá, 1953.

Posada Eduardo. Bibliografía Bogotana. 2 vol. Biblioteca de Historia Nacional (vols. XVI y XXXVI), Bogotá: Imprenta de Arboleda y Valencia, Imprenta Nacional I917-1925.

Vegalara, Humberto. Bibliografía comentada sobre el desarrollo económico y la economía colombiana. Bogotá: Centro de Estudios sobre Desarrollo Económico, Universidad de Los Andes, 1959.

Wiesner Durán, Eduardo. Bibliografía Comentada sobre el Desarrollo Económico y la Economía Colombiana. Vol. II. Bogotá: Centro de Estudios sobre Desarrollo Económico. Universidad de Los Andes, 1961.

\section{III. Índices}

Academia Colombiana de Historia, índice General del Boletín de historia y Antigüedades. Volúmenes I-XXVIII, 1902-1952. Editado por Daniel Ortega Ricaurte. Bogotá: Editorial Pax, 1953.

Archivo Histórico Nacional, índices del Archivo Nacional: Sección Colonia. 5 vol. Bogotá, 1944 y ss.

Biblioteca Nacional de Colombia. Catálogo de todos los periódicos que existen desde su fundación hasta el año de 1935. 2 vol. Bogotá: Editorial "El Gráfico”, 1936.

índice del "Papel Periódico Ilustrado" y del "Colombiano ilustrado". Instituto Caro y Cuervo: Serie Bibliográfica. Bogotá: Imprenta Patriótica del Instituto Caro y Cuervo, 1961.

Ortega Torres, José J. índice de El Repertorio Colombiano. Instituto Caro y Cuervo: Serie Bibliográfica. Bogotá: Imprenta Patriótica del Instituto Caro y Cuervo, 1961.

IV. Colecciones 
BIBLIOTECA DE HISTORIA DE COLOMBIA. Publicada por la Academia Colombiana de Historia (100 vols. aproximadamente). Especial para independencia y república. Contiene importantes títulos corno la Bibliografía Bogotana de Eduardo Posada, básica para el estudio del siglo XVIII y primeras décadas del XIX. Inventarios de libros, folletos, hojas sueltas, etc., publicadas en Bogotá sobre todo en el período de la Independencia. El libro de Finestrad, El Vasallo instruido, para fines del siglo XIX. Las Cartas de Caldas. Las Cualidades y Riquezas del Nuevo Reino de Granada, de Basilio V. de Oviedo, para la Historia Social y Económica del siglo XVIII. Las Relaciones del Mando de los Virreyes, para la Historia Política, Social y Económica del siglo XVIII:

y la Historia del Padre Gilij, para esta misma época (Parte referente a Nueva Granada).

BIBLIOTECA POPULAR DE CULTURA COLOMBIANA. Publicada por el Ministerio de

Educación Nacional (150 vols. aproximadamente). Especial para Colonia y República (siglo XIX). Contiene reediciones de la Historia General de las Conquistas del Nuevo Reino de Granada de Piedrahita; Historia de la Provincia de San Antonio del Nuevo Reino de Granada de Zamora. También obras como la Historia del Nuevo Reino de Granada de Joaquín Acosta y varios tomos de viajeros extranjeros en el Nuevo Reino de Granada, como Mollien, le Moyne, Saffray. Memorias importantes para la Historia Social y Política del siglo XIX como las de Camacho Roldán, José H. López, Obando, Jose M. Samper y complicaciones como las Constituciones de Colombia de Pombo y Guerra. También Crónicas como las de Cordovez Moure y Pedro M. Ibáñez y el Seminario del Nuevo Reino de Granada de Caldas (3 vols.).

BIBLIOTECA DE AUTORES COLOMBIANOS. Publicada por el Ministerio de Educación Nacional. Especial para la Historia Política (siglo XIX). Contiene reediciones de libros importantes para la Historia Política del siglo XIX, como las memorias de Posada Gutiérrez, Los sueños de Marco Fidel Suárez, El Derecho Constitucional de José Ma. Samper, y títulos importantes para la Historia Literaria y de las Ideas, como obras escogidas de Rafael M. Carrasquilla, Sermones de Cartés Lee, Obras Poéticas de Silva y Pombo, y Ensayos de Autores Contemporáneos. También la reedición de las Noticias Historiales de Fray Pedro Simón.

\section{BIBLIOTECA DE LA PRESIDENCIA DE LA REPÚBLICA DE COLOMBIA (50 vols.)}

Especial para la Colonia y la República. Comprende reediciones de libros básicos Para el estudio de Colombia y el Siglo XVIII, corno Elegías de Juan de Castellanos (4 vols.); La Recopilación Historial de Aguado (4 vols.); El Orinoco llustrado de Gumilla; Las Maravillas de la Naturaleza de Juan de Santa Gertrudis, para el siglo XVIII; La Historia de las Misiones de los Llanos de Casanare y de los ríos del Orinoco y Meta del Padre Juan Rivero y de este mismo autor el Teatro del Desengaño, importante para el estudio de las ideas en el siglo XVI y XVIII; además libros importantes para la Historia Social y Económica del siglo XIX, como la Peregrinación de Alfá de Manuel Ancízar; La Geografía de la Nueva Granada, de Eliséo Reclus; La Autobiografía dc J. M. Restrepo; La Historia de la Literatura Colombiana de Vergara y Vergara.

BIBLIOTECA DE LITERATURA COLOMBIANA SAMPER ORTEGA (100 vols.) Especial para la Literatura, siglos XIX y XX. Está dividida en diez series de a 10 volúmenes cada una. Las series son: Teatro, Ensayo, Periodismo, Novela, Crónicas, Oratoria. Poesía, Memorias, Cuentistas, Costumbristas. Comprende autores del siglo XIX y contemporáneos. Cada tomo está precedido de un estudio biográfico de los autores 
incluidos. Es una verdadera enciclopedia de la Literatura Colombiana, donde se encuentran libros de muy difícil consecución como la Expedición Botánica de Zerda; Las Antigüedades Neogranadinas, de Uricochea y piezas de teatro y poesía popular, la lírica, artículos periodísticos, oraciones conmemorativas, etc., posee un tomo de índices.

BIBLIOTECA EDUARDO SANTOS. Publicada por la Academia Colombiana de Historia (20 vols. aproximadamente). Especial para el siglo XIX. Comprende tomos cononografías útiles para la Historia Política y Cultural de la Epoca Colonial, y obras como El 20 de Julio y Nariño Periodista (Reproducción de la Bagatela), importantes para el estudio del movimiento de Independencia.

ARCHIVO DE LA ECONOMIA NACIONAL. Publicado por el Banco de la República (20 vols. aproximadamente). Especial para Historia Económica, siglos XIX y XX. Ha publicado obras preciosas para la Historia Económica y Social de siglo XIX, como las Memorias Económicas de los Virreyes; Viajes del Coronel Hamilton; Geografía de Codazzi (3 vols.); El Dorado de Ernest Rotlisberger; Las Minas de Oro y Plata de Colombia, de Vicente Restrepo (Historia de la Minería Colombiana).

DOCUMENTOS PARA LA HISTORIA DE COLOMBIA. Publicados por la Academia Colombiana de Historia, bajo la dirección de Juan Fride (10 vols.) Especial para Conquista (siglo XVI). Antonio B. Cuervo, Colección de Documentos Inéditos sobre la Geografía y la Historia de Colombia. Bogotá, 1891-92, (4 vols.) Colmenares, M. Melo, D. Fajardo, Fuentes Coloniales para la Historia del Trabajo en Colombia. Bogotá. 1968 (I vol.)

HISTORIA EXTENSA DE COLOMBIA. Publicada bajo la dirección de la Academia Colombiana de Historia. Bogotá, 1965 y ss. (20 vols.) publicados hasta hoy.

\section{Bibliografía}

Época Colonial (siglos xvi, xvii y xviii,): Sociedad, economía, instituciones y cultura

Acuerdos de la Real Audiencia del Nuevo Reino de Granada. Publicaciones del Archivo Nacional de Colombia, dirigida por Enrique Ortega Ricaurte, Bogotá, 1957 ( Vols.).

Cabildos de Santa Fe de Bogotá. Publicación de/ Archivo Nacional de Colombia, dirigida por Enrique Ortega Ricaurte. Bogotá, 1957.

Gutiérrez de Pineda, Virginia. La Familia en Colombia (Vol. I). Bogotá, 1963.

Hernández Rodríguez, Guillermo. De los Chibchas y la Colonia y a la República, Bogotá, 1949.

Ospina Vásquez, Luis. Industria y Protección en Colombia. Medellín, 1955.

Ots Capdequi, José María. El Estado Español en las Indias, F.C.E. México, 1946.

Ots Capdequi, José María. Instituciones de Gobierno del Nuevo Reino de Granada, en el siglo XVIII, Bogotá, 1750.

Relaciones de Mando de los Virreyes. Biblioteca de Historia de Colombia. Publicada por la Academia de Historia de Colombia, Bogotá, 1911. Imprenta Nacional.

Rosemblat, Ángel. La Población Indígena y el Mestizaje en América. Ed. Nova. Buenos Aires, 1954, 2 vols.

Silvestre, Francisco. Descripción del Nuevo Reino de Granada. B. P. C. C., Bogotá, 1950. 
Arbeláez Camacho, Carlos y Sebastián Santiago, E/ Arte en Colombia, en Historia Extensa de Colombia (150 vol.), Bogotá, 1967.

Colmenares, Germán, Las Haciendas de los Jesuitas en el Nuevo Reino de Granada, Bogotá, 1969.

Colmenares, Germán. La Providencia de Tunja en e/ Nuevo Reino de Granada, Bogotá, 1970.

Curcio Altamar, Antonio. Evolución de la Novela en Colombia. I.C. y C. Bogotá, 1957.

Fray José Abel Salazar, Los Estudios Eclesiásticos Superiores en el Nuevo Reino de Granada. Madrid, 1946.

García Baca, Juan David, Antología del Pensamiento Filosófico en Colombia. (16471761). B.P.R.C., Bogotá, 1955.

Giraldo Jaramillo, Gabriel. La Pintura en Colombia. F.C.E. México, 1948.

Gómez Restrepo, Antonio. Historia de la Literatura Colombiana. B. A.C. Bogotá. 1956 (4 vols.).

González, Margarita. El Resguardo en el Nuevo Reino de Granada, Bogotá, 1970.

Jaramillo Uribe, Jaime. Ensayos de Historia Social Colombiana, Bogotá, 1970.

Liévano Aguirre, Indalecio. Los Grandes Conflictos Económicos y Sociales de Nuestra Historia, Bogotá ,s.f.

López de Mesa, Luis. introducción a la Historia de la Cultura en Colombia. Bogotá, 1930.

Porras Troconis, Gabriel. Historia de la Cultura en N. Granada. Consejo Superior de Investigaciones Científicas. Madrid, 1952.

Rivas Sacconi, José Manuel. El Latín en Colombia. L.C. y C. Bogotá, 1949.

República (siglos xix y xx): Estado, sociedad, economía y cultura

Arrubla, Mario. Estudios sobre Subdesarrollo Colombiano, Bogotá, 1968.

Bushnell, David. El Régimen de Santander en la Gran Colombia, Bogotá, 19 ..

Camacho Roldán, Salvador. Memorias. Biblioteca Popular de Autores Colombianos,

Bogotá, 1946, 2 vols.

Caro, Miguel Antonio. Estudios Constitucionales. B.P.C.C. Bogotá, 1951.

Codazzi, Agustín y Comisión Corográfica. Geografía Física y Política de las Provincias de

la Nueva Granada. Banco de la República, Bogotá, 1958 (3 vols.)

Cordovéz Moure, José María. Reminiscencias. B. P. C. C. Bogotá, 1942, 8 vols.

Cuervo, Ángel y Rufino J. Vida de Rufino Cuervo y Noticias de su época. B. P. C.C., Bogotá, 1946, 2 vols.

Gómez Hoyos, Rafael. La Revolución Granadina de 1810, 2 vols.

Groot, José Manuel. Historia Eclesiástica y Civil del Nuevo Reino de Granada, 2a. Ed. B.

A. C. Bogotá, 1953, 5 vols.

Hamilton J. P. Viajes por el interior de Colombia, A. E. M. E. R., Bogotá, 1955, 2 vols.

Jaramillo, Uribe, Jaime. Antología del Pensamiento Político Colombiano, Bogotá, 1970. 2 vols.

Le Moyne, Augusto. Víajes y Estancias en América del Sur. B. P. C. C. Bogotá, 1945.

López Toro, Alvaro. Migración y Cambio Social en Antioquia durante el siglo XIX, Bogotá, 1968.

Martz, John D. Colombia, un Estudio de Política Contemporánea, Bogotá, 1970.

Molien, G. Viaje por la República de Colombia en 1823. H.P. C.C., Bogotá, 1944.

Nieto Arteta, Luis Eduardo. Economía y Cultura en la Historia de Colombia. Bogotá.

Ospina Vásquez, Luis. Industria y Protección en C'Colombia. Medellín, 1955.

Pombo, Antonio y Guerra, José Joaquín. Constituciones en Colombia. B. P.C. C., Bogotá, 1951,4 vols.

Posada Gutiérrez, Joaquín. Memorias Histórico-Políticas. B. P. C.C. Bogotá, 1951. 6 vols. 
Restrepo, José Manuel. Historia de la Revolución en la República de Colombia, 3a. Ed.

B.P.C.C. Bogotá, 1950,8 vols.

Rodríguez Plata, Horacio. La inmigración Alemana al Estado Soberano de Santander, en el siglo XIX. Bogotá, 1968.

Rothlisberger, Walter. El Dorado. AEMBER, Bogotá, 1953.

Samper, Armando. Importancia del Café en el Comercio Exterior de Colombia. Bogotá, 1948.

Samper, José María. Historia de un Alma. B.P.C.C., Bogotá. 1948 (2 vols.)

Samper, José María. Tratado de Derecho Constitucional, B.P.C.C., Bogotá, 1951. 2 vols. Urrutia Miguel. Historia del Sindicalismo en Colombia, Bogotá, 1969.

\section{Abreviaturas}

B.P.C.C.: Biblioteca Popular de Cultura Colombiana.

BAC.: Biblioteca de Autores Colombianos.

A.E.N.B.R.: Archivo de la Economía Nacional del Banco de la República

B.L.C.S.O.: Biblioteca de Literatura Colombiana "Samper Ortega".

B.H.N.A.C.H.: Biblioteca de la Historia Nacional de la Academia Colombiana de Historia.

B.P.R.C.: Biblioteca de la Presidencia de la República de Colombia

B.E.S.A.C.H.: Biblioteca Eduardo Santos de la Academia Colombiana de Historia. 